\title{
Integrated pollution prevention and control: choosing the best available technique by using a cost-benefit approach
}

\author{
E. Brizio \& G. Genon \\ Turin Polytechnic, Italy
}

\begin{abstract}
European directive 96/61/CE concerning integrated pollution prevention and control was completely received in Italy at the beginning of 2005 by D.Lgs. 59/2005. The contents of the directive are now widely applied within the authorization procedure of many industrial activities in Italy, such as pulp and paper production, cement factories, foundries, chemical installations and so on. The hardest decision that competent authorities have to take within the procedure relates to the definition of the emission limit values; these limit values and the equivalent parameters and technical measures shall be based on the so-called "best available techniques (B.A.T.)". The directive 96/61/CE, art. 9, says that the emission limit values should be decided "taking into account the technical characteristics of the installation concerned, its geographical location and the local environmental conditions. In all circumstances, the conditions of the permit shall contain provisions on the minimization of long-distance or transboundary pollution and ensure a high level of protection for the environment as a whole."

In the present paper we try to define the proper emission limit values for nitrogen oxides emitted by a cement factory in Italy by comparing the costs of the techniques applied to control emissions with the environmental benefit arising from the reduction of the emissions. The assessment of the external costs associated to the impact of pollutants deriving from cement production has been carried out by using the ExternE approach, a research program of the European Commission based on atmospheric dispersion modelling, exposure-response functions and monetary valuations. On the other hand, the costs of the abatement technologies are assessed on the basis of the investment and operating costs reported for the cement industry.
\end{abstract}

Keywords: I.P.P.C., B.A.T., cost-benefit, ExternE, NO ${ }_{X}$, cement kiln, exposureresponse functions, nitrates, regional scale. 


\section{Introduction}

In the present paper we basically analyse the technical features and the possibilities of containing the atmospheric emissions of a cement kiln placed in North Western Italy. The kiln is a typical long dry rotary kiln which can produce 150.000 tonne/year of clinker and it is part of an industrial complex with 3 cement kilns. We focus our attention on the emissions of nitrogen oxides, probably the main environmental impact of the cement industry.

The flow emitted by the analysed kiln is approximately $55.000 \mathrm{Nm}^{3} / \mathrm{h}$, with a humidity volume of $10 \%$ and a oxygen content near $11 \%$ (vol/vol for dry smoke). The flue gas temperature measures $170{ }^{\circ} \mathrm{C}$, the stack height is $67 \mathrm{~m}$ and the stack diameter is $2,6 \mathrm{~m}$. The yearly mean concentration for $\mathrm{NO}_{\mathrm{X}}$ is around $1250 \mathrm{mg} / \mathrm{Nm}^{3}$ for wet gases (approximately $1527 \mathrm{mg} / \mathrm{Nm}^{3}$, expressed as $\mathrm{NO}_{2}$, dry gas, $\mathrm{O}_{2} @ 10 \%$ ). The cement factory falls within the European directive 96/61/CE concerning integrated pollution prevention and control (I.P.P.C.) and consequently it is forced to apply best available techniques (B.A.T.) in order to limit its impact on the environment, reducing, in particular, $\mathrm{NO}_{\mathrm{X}}$ emissions. Obviously, every B.A.T. means different investment and operating costs in order to obtain lower emission levels. On the other hand, the avoided emissions represent environmental benefits which are rarely determined with a consistent approach: in the following pages we try to describe a reliable cost-benefit approach, applied to a real case, so as to determine the proper abatement technique and the corresponding reduction efficiency.

\section{B.A.T. costs and emission levels}

The Reference Document on best available techniques in the Cement and Lime industries [1] gives a satisfactory overview of the present emission levels associated with cement production and the techniques (feasibility, emission levels, costs) that may have a positive effect on (i.e. reduce) emissions arising during the manufacture of cement. Table 1 reports a summary of the B.A.T. for cement kilns: the reported emissions refer to daily averages, dry gas, $273 \mathrm{~K}$, $101.3 \mathrm{kPa}$ and $10 \% \mathrm{O}_{2}$, the investment costs are expressed in $10^{6}$ euros (normally referring to a kiln capacity of 3000 tonne clinker/day, so that they are largely overestimated with respect to the analysed kiln) and the operating costs in euros/tonne of clinker.

As one can easily notice, the B.A.T. for reducing $\mathrm{NO}_{\mathrm{X}}$ emissions from a long dry rotary kiln are essentially:

- Primary measures to control $\mathrm{NO}_{\mathrm{X}}$ emissions

- Flame cooling

- Low-NO burner

- Selective catalytic reduction (SCR).

On a sector level, the majority of kilns in the European Union is said to be able to achieve less than $1200 \mathrm{mg} / \mathrm{m}^{3}$ (dry gas, $\mathrm{O}_{2} @ 10 \%$ ) with primary measures; this emission level is usually proposed by industrial administrators within the I.P.P.C. authorization procedure, in association with Low $\mathrm{NO}_{\mathrm{X}}$ burner. 
On the other hand, the B.A.T. reference document reports very low emission levels $\left(400 \mathrm{mg} / \mathrm{m}^{3}\right)$ associated with the use of primary measures (flame cooling and Low-NOx burner), so that the BAT emission level associated with the use of these techniques is considered to be in the range 200-500 $\mathrm{mg} \mathrm{NO} \mathrm{NO}_{\mathrm{X}} / \mathrm{m}^{3}$ expressed as $\mathrm{NO}_{2}$ on a daily average basis.

Table 1: $\quad$ Overview of techniques for controlling $\mathrm{NO}_{\mathrm{X}}$.

\begin{tabular}{|c|c|c|c|c|c|c|}
\hline \multirow[t]{2}{*}{ Technique } & \multirow{2}{*}{$\begin{array}{l}\text { Kiln systems } \\
\text { applicability }\end{array}$} & \multirow{2}{*}{$\begin{array}{l}\text { Reduction } \\
\text { efficiency }\end{array}$} & \multicolumn{2}{|c|}{ Reported emissions } & \multicolumn{2}{|c|}{ Reported costs } \\
\hline & & & $\mathrm{mg} / \mathrm{m}^{3}$ & $\mathrm{~kg} /$ tonne & investment & operating \\
\hline Flame cooling & All & $0-50 \%$ & \multirow{2}{*}{$400-$} & \multirow{2}{*}{$0.8-$} & $0.0-0.2$ & $0.0-0.5$ \\
\hline Low- $\mathrm{NO}_{\mathrm{x}}$ burner & All & $0-30 \%$ & & & $0.15-0.8$ & 0 \\
\hline \multirow{2}{*}{ Staged combustion } & Precalciner & \multirow{2}{*}{$10-50 \%$} & \multirow{2}{*}{$<500-1000$} & \multirow{2}{*}{$<1.0-2.0$} & $0.1-2$ & 0 \\
\hline & Preheater & & & & $1-4$ & 0 \\
\hline Mid-kiln firing & Long & $20-40 \%$ & No info. & - & $0.8-1.7$ & No info. \\
\hline Mineralised clinker & All & $10-15 \%$ & No info. & - & No info. & No info. \\
\hline SNCR & $\begin{array}{c}\text { Preheater and } \\
\text { Precalciner }\end{array}$ & $10-85 \%$ & $200-800$ & $0.4-1.6$ & $0.5-1.5$ & $0.3-0.5$ \\
\hline $\begin{array}{l}\mathrm{SCR} \text { - data from } \\
\text { pilot plants only }\end{array}$ & Possibly all & $85-95 \%$ & $100-200$ & $0.2-0.4$ & $\begin{array}{l}\text { ca. } 2.5 \\
3.5-4.5\end{array}$ & $\begin{array}{c}0.2-0.4 \\
\text { No info. }\end{array}$ \\
\hline
\end{tabular}

There was also a view that selective catalytic reduction (SCR) is BAT with an associated emission level of 100-200 $\mathrm{mg} \mathrm{NO} \mathrm{NO}_{\mathrm{X}} / \mathrm{m}^{3}$ (as $\mathrm{NO}_{2}$ ), based upon SCR being regarded as an available and economically viable technique. This conclusion is drawn from feasibility studies and successful pilot tests. There are at least three suppliers in Europe that offers full scale SCR to the cement industry with performance levels of $100-200 \mathrm{mg} / \mathrm{m}^{3}$.

Based on the described features, within our analysis, we consider 3 different emission levels achievable with B.A.T.; Table 2 reports these levels and the corresponding costs, calculated on the basis of the analysed kiln capacity.

Table 2: $\quad$ NO2 emission levels considered in the cost-benefit analysis.

\begin{tabular}{|c|c|c|c|c|}
\hline \multirow{2}{*}{$\begin{array}{l}\mathrm{mg} \mathrm{NO} \mathrm{NO}_{2} / \mathrm{Nm}^{3} \\
\left.\text { (dry gas, } \mathrm{O}_{2} @ 10 \%\right)\end{array}$} & \multirow{2}{*}{$\begin{array}{l}\mathrm{mg} \mathrm{NO} / \mathrm{Nm}^{3} \\
\text { (wet gas) }\end{array}$} & \multicolumn{2}{|c|}{ Reported B.A.T. costs } & \multirow[b]{2}{*}{ notes } \\
\hline & & $\begin{array}{c}\text { Investment } \\
(€)\end{array}$ & $\begin{array}{c}\text { Operating } \\
(€ / y)\end{array}$ & \\
\hline 1527 & 1250 & - & - & no B.A.T. \\
\hline 1200 & 981 & $\begin{array}{l}150.000- \\
800.000\end{array}$ & - & Proposed level \\
\hline 500 & 409 & $0-200.000$ & $0-75.000$ & Flame cooling \\
\hline 500 & 409 & $\begin{array}{l}150.000- \\
800.000\end{array}$ & - & $\begin{array}{l}\text { Low-NO } \\
\text { burner }\end{array}$ \\
\hline 200 & 163 & $\begin{array}{l}2.500 .000- \\
4.500 .000\end{array}$ & $\begin{array}{l}30.000- \\
60.000\end{array}$ & SCR \\
\hline
\end{tabular}

\section{Environmental benefit assessment}

Externalities deriving from any production cycle represents the costs imposed on society as well as on the environment that are not accounted for by the producers 
and consumers of goods, that is which are not included in the market price; external costs constitute an heavy market failure which justifies strong intervention policies. The ExternE project [2] is the first and, at the moment, the most advanced and reliable attempt to use a consistent methodology to assess the external costs deriving from airborne pollutants since it comprises valuation techniques which integrate technical-scientific and economic analysis. The externalities evaluation techniques are divided into direct and indirect methods: as concerns the external costs due to pollution, the direct techniques characterize the facility to be analysed (technical features, emitted pollutants..), determine the pollutants pathway within a certain distance and measure the impacts on particular receptors. The direct method doesn't perform economic assessments but its technical analysis, based on atmospheric dispersion modelling and exposure-response toxicological functions, can evaluate, in statistical terms, the probability of certain negative events (for example, the probability of some respiratory pathology or the loss of crop quantities). On the other hand, the indirect methods are based on the perception of the damage that people think to receive as a consequence of the atmospheric pollution; consequently, these techniques observe the real behaviours of people who suffer from the impact and obtain from these behaviours a purely economic valuation. The underlying principle in monetary valuation is to obtain the willingness to pay (WTP) of an affected individual to avoid a negative impact, or the willingness to accept (WTA) payment as compensation if a negative impact takes place.

Obviously, the best approach for an exhaustive valuation of the externalities is the integration of both the techniques: the ExternE methodology applies the indirect analysis downstream from the direct method. The analysis is based on 4 phases and proceeds in a sequential way from emissions towards the impact assessment and the respective monetization. The first phase individuates the main technological features of facility, the pollutant concentrations $\left(\mathrm{mg} / \mathrm{Nm}^{3}\right)$, the emission rates $(\mathrm{g} / \mathrm{kWh})$ and the characteristics of the stacks (number, height and diameter). The second phase consists of the calculation of the year mean concentration of the pollutants at the ground level on the basis of atmospheric dispersion models. The third phase individuates the subjects exposed to the pollutants in the considered area and the correspondent characteristics (the number, the distribution and the age groups of the hit people, types and distribution of crops..). In the same phase, proper exposure-response functions are applied in order to determine the impacts on the receptors (these impacts are quantified as year additional cases of chronic bronchitis or asthma attacks for the human health, yield loss for the crops, etc..). As concerns the analysis of the effects on human health, which generally constitute the main contribute to the total monetary damage, the correspondent exposure-response functions are expressed as cases/(year*person* $\left.\mu \mathrm{g} / \mathrm{m}^{3}\right)$; this approach is clearly linear, without thresholds. Finally, the fourth phase monetizes the calculated physical impacts on the basis of the WTP or WTA techniques described before. Table 3 reports the exposure-response functions and the corresponding monetization suggested by the ExternE project [2] for the receptor 'human health'. 
Table 3: Exposure-response functions in ExternE for the receptor 'human health'.

\begin{tabular}{|c|c|c|c|c|c|}
\hline & $\begin{array}{c}\text { Health end } \\
\text { point }\end{array}$ & Reference & receptor & $\begin{array}{c}\mathbf{f}_{\mathrm{er}} \\
(\text { cases } / \text { year/ } \\
\left.\text { person } / \mu \mathrm{g} / \mathrm{m}^{3}\right)\end{array}$ & $\begin{array}{c}\text { Unit cost } \\
\left(\text { EURO }_{2000} / \text { case }\right)\end{array}$ \\
\hline \multirow{13}{*}{ 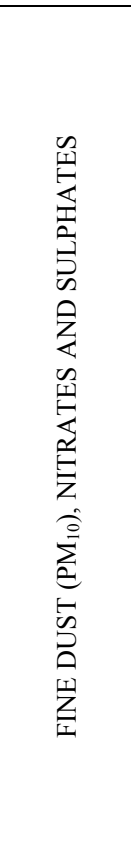 } & $\begin{array}{c}\text { Bronchodilator } \\
\text { usage }\end{array}$ & $\begin{array}{c}\text { Dusseldorp et al., } \\
1995\end{array}$ & $\begin{array}{l}\text { Asthmatic } \\
\text { adults }\end{array}$ & $1,63 \mathrm{E}-01$ & 40 \\
\hline & Cough & $\begin{array}{c}\text { Dusseldorp et al., } \\
1995\end{array}$ & $\begin{array}{l}\text { Asthmatic } \\
\text { adults }\end{array}$ & $1,68 \mathrm{E}-01$ & 45 \\
\hline & $\begin{array}{c}\text { Lower } \\
\text { Respiratory } \\
\text { Symptoms }\end{array}$ & $\begin{array}{c}\text { Dusseldorp et al., } \\
1995\end{array}$ & $\begin{array}{l}\text { Asthmatic } \\
\text { adults }\end{array}$ & $6,06 \mathrm{E}-02$ & 8 \\
\hline & $\begin{array}{c}\text { Bronchodilator } \\
\text { usage }\end{array}$ & $\begin{array}{c}\text { Roemer et al., } \\
1993\end{array}$ & $\begin{array}{l}\text { Asthmatic } \\
\text { children }\end{array}$ & $7,75 \mathrm{E}-02$ & 40 \\
\hline & Cough & $\begin{array}{c}\text { Pope and } \\
\text { Dockery, } 1992\end{array}$ & $\begin{array}{l}\text { Asthmatic } \\
\text { children }\end{array}$ & $1,33 \mathrm{E}-01$ & 45 \\
\hline & $\begin{array}{c}\text { Lower } \\
\text { Respiratory } \\
\text { Symptoms }\end{array}$ & $\begin{array}{c}\text { Roemer et al., } \\
1993\end{array}$ & $\begin{array}{l}\text { Asthmatic } \\
\text { children }\end{array}$ & $1,03 \mathrm{E}-01$ & 8 \\
\hline & $\begin{array}{c}\text { Congestive Heart } \\
\text { Failure }\end{array}$ & $\begin{array}{l}\text { Schwartz and } \\
\text { Morris, } 1995\end{array}$ & $\begin{array}{l}\text { Adults over } \\
65\end{array}$ & $1,85 \mathrm{E}-05$ & 3.260 \\
\hline & Chronic cough & $\begin{array}{c}\text { Dockery et al., } \\
1989 \\
\end{array}$ & Children & $2,07 \mathrm{E}-03$ & 240 \\
\hline & $\begin{array}{c}\text { Restricted } \\
\text { Activity Days }\end{array}$ & Ostro, 1987 & Adults & $2,50 \mathrm{E}-02$ & 110 \\
\hline & $\begin{array}{c}\text { Chronic } \\
\text { Bronchitis }\end{array}$ & $\begin{array}{c}\text { Abbey et al., } \\
1995\end{array}$ & Adults & $2,45 \mathrm{E}-05$ & 169.330 \\
\hline & $\begin{array}{l}\text { Respiratory } \\
\text { Hospital } \\
\text { Admissions } \\
\end{array}$ & Dab et al., 1996 & $\begin{array}{c}\text { Entire } \\
\text { population }\end{array}$ & $2,07 \mathrm{E}-06$ & 4.320 \\
\hline & $\begin{array}{c}\text { Cerebrovascular } \\
\text { Hospital } \\
\text { Admissions } \\
\end{array}$ & $\begin{array}{c}\text { Wordley et al., } \\
1997\end{array}$ & $\begin{array}{c}\text { Entire } \\
\text { population }\end{array}$ & $5,04 \mathrm{E}-06$ & 16.730 \\
\hline & $\begin{array}{c}\text { Chronic mortality } \\
\text { (YOLL) }\end{array}$ & Pope et al., 1995 & $\begin{array}{c}\text { Entire } \\
\text { population }\end{array}$ & $1,57 \mathrm{E}-04$ & 96.500 \\
\hline $\mathrm{SO}_{2}$ & $\begin{array}{l}\text { Respiratory } \\
\text { Hospital } \\
\text { Admissions } \\
\end{array}$ & $\begin{array}{c}\text { Ponce de Leon, } \\
1996\end{array}$ & $\begin{array}{c}\text { Entire } \\
\text { population }\end{array}$ & $2,04 \mathrm{E}-06$ & 4.320 \\
\hline & $\begin{array}{l}\text { Acute mortality } \\
\text { (YOLL) }\end{array}$ & $\begin{array}{c}\text { Anderson \& } \\
\text { Toulomi, } 1996\end{array}$ & $\begin{array}{c}\text { Entire } \\
\text { population }\end{array}$ & $6,16 \mathrm{E}-06$ & 165.700 \\
\hline $\mathrm{CO}$ & $\begin{array}{c}\text { Congestive Heart } \\
\text { Failure }\end{array}$ & $\begin{array}{l}\text { Schwartz and } \\
\text { Morris, } 1995\end{array}$ & $\begin{array}{l}\text { Adults over } \\
65\end{array}$ & $5,64 \mathrm{E}-07$ & 3.260 \\
\hline $\mathrm{PAH}$ & Lung cancer & U.S.EPA, 1990 & $\begin{array}{c}\text { Entire } \\
\text { population }\end{array}$ & $0,1 / 70 * 0,9$ & 3.400 .000 \\
\hline РАН & Non fatal cancer & U.S.EPA, 1990 & $\begin{array}{c}\text { Entire } \\
\text { population }\end{array}$ & $0,1 / 70 * 0,1$ & 485.943 \\
\hline $\mathrm{PCDD} / \mathrm{DF}$ & Cancer & LAI & $\begin{array}{c}\text { Entire } \\
\text { population }\end{array}$ & $1,4 / 70$ & 3.400 .000 \\
\hline Cadmium & Cancer & LAI & $\begin{array}{c}\text { Entire } \\
\text { population }\end{array}$ & $1,2 / 100 / 70$ & 3.400 .000 \\
\hline Chromium & Cancer & WHO & $\begin{array}{c}\text { Entire } \\
\text { population }\end{array}$ & $4 / 100 / 70$ & 3.400 .000 \\
\hline Arsenic & Cancer & LAI & $\begin{array}{c}\text { Entire } \\
\text { population }\end{array}$ & $4 / 1000 / 70$ & 3.400 .000 \\
\hline Nickel & Cancer & U.S. EPA & $\begin{array}{c}\text { Entire } \\
\text { population }\end{array}$ & $4 / 1000 / 70$ & 3.400 .000 \\
\hline Benzene & Cancer & U.S. EPA & $\begin{array}{c}\text { Entire } \\
\text { population }\end{array}$ & $8 / 10^{\wedge} 6 / 70$ & 3.400 .000 \\
\hline
\end{tabular}

The ExternE methodology can be applied both on the local scale and the regional scale (European-wide). As a matter of fact, the local scale focuses on 
distance up to $20 \mathrm{~km}$, where the formation of secondary pollutants, that is nitrates and sulphates deriving from atmospheric chemical reactions, can be neglected.

The ECOSENSE software package [3] has been developed within the ExternE project to support and standardize the assessment of the main environmental impacts deriving from the exposition to the atmospheric pollutants. The ECOSENSE software can calculate the total monetary damage both on a local scale $(100 \mathrm{~km} * 100 \mathrm{~km}$ centred on the site of the plant, with a spatial resolution of $10 \mathrm{~km}$ ) and on a regional scale (the resolution is $100 \mathrm{~km}$ ). As far as the regional scale is concerned, the concentrations at the ground level are calculated by means of the Lagrangian model Windrose Trajectory Model (WTM), developed by the Harwell Laboratories and included in the ECOSENSE model. The Windrose Trajectory Model employs an air parcel with a constant mixing height of $800 \mathrm{~m}$, moving with a representative wind speed, and considers the atmospheric chemical reactions; as a consequence, it can calculate the concentrations of the acid species formed in atmosphere (i.e. nitrates and sulphates).

Within the present study, it is important to remember that nitrogen oxides are significant precursors to nitrates (secondary particulates) and ozone.

Some studies reported epidemiological evidences regarding $\mathrm{NO}_{\mathrm{X}}$ but the broad trust was that apparent $\mathrm{NO}_{\mathrm{X}}$ effect were best understood not as casual, but as $\mathrm{NO}_{\mathrm{X}}$ being a surrogate for some mixture of pollution. The APHEA results reported positive associations between $\mathrm{NO}_{2}$ and daily mortality or respiratory hospital admissions in several European cities. Consequently it is possible to propose exposure-response function for $\mathrm{NO}_{\mathrm{X}}$. However it is recommended that the E-R functions for $\mathrm{NO}_{\mathrm{X}}$ are used exclusively for sensitivity analyses.

On the other hand, the exposure-response functions for secondary pollutants deriving from $\mathrm{NO}_{\mathrm{X}}$, such as nitrates and ozone, are reliable enough to be used without problems. In spite of this, the assessment of the effect of emission reductions on ozone concentrations at the local scale probably represents the most difficult problem within atmospheric transport modelling for ExternE (Friedrich and Bickel [4]). As a consequence, in the present work, in order to define the environmental benefits arising from the reduction of $\mathrm{NO}_{\mathrm{X}}$ emissions, we used the ECOSENSE model on the regional scale to determine the total monetary damage due to nitrates derived from nitrogen oxides emitted by the analysed cement kiln. Moreover, since public administrations are very interested in local context, we applied the exposure-response functions for $\mathrm{NO}_{\mathrm{X}}$ on the local scale, so as to get some general information.

\section{Results}

Table 4 reports the monetary damages, corresponding to each health end point indicated by the ExternE project for nitrates, calculated by ECOSENSE on the regional scale for the "no B.A.T." scenario (i.e., current emission levels, 1527 $\mathrm{mg} / \mathrm{Nm}^{3}$, dry gas, $\mathrm{O}_{2} @ 10 \%$ ). As one can easily observe, the total damage is very large $\left(7.463 € / \mathrm{t}\right.$ of emitted $\left.\mathrm{NO}_{2}\right)$ due to the high number of individuals hit 
by the impact all over Europe. The main contribution to the total damage is constituted by the chronic mortality $(77 \%)$, followed by the chronic bronchitis $(12 \%)$ and the restricted activity days $(8 \%)$; in particular, the calculated nitrates concentration, due to the $\mathrm{NO}_{2}$ emissions of the analysed kiln, causes respectively 36 YOLL per year (Years Of Life Lost distributed over the resident population), 3,2 additional cases of chronic bronchitis per year and 3.253 restricted activity days per year.

Table 4: Damages on the regional scale for the "no B.A.T." scenario.

\begin{tabular}{|c|c|c|c|c|c|}
\hline \multicolumn{6}{|c|}{$\mathrm{NO}_{\mathrm{X}}: 1527 \mathrm{mg} / \mathrm{Nm}^{3}$ dry gas, $\mathrm{O}_{2} @ 10 \%$} \\
\hline & $\begin{array}{c}\text { Health end } \\
\text { point }\end{array}$ & Reference & receptor & $\begin{array}{c}\text { Impacts } \\
\text { (cases/year) }\end{array}$ & $\begin{array}{c}\text { Damage } \\
\left(\text { EURO }_{2000}\right) / \mathbf{y}\end{array}$ \\
\hline \multirow{13}{*}{ 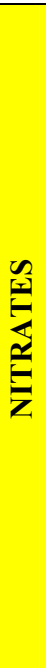 } & Bronchodilator usage & Dusseldorp et al., 1995 & Asthmatic adults & 742,15 & 29.679 \\
\hline & Cough & Dusseldorp et al., 1995 & Asthmatic adults & 763,17 & 34.353 \\
\hline & $\begin{array}{c}\text { Lower Respiratory } \\
\text { Symptoms }\end{array}$ & Dusseldorp et al., 1995 & Asthmatic adults & 275,98 & 2.208 \\
\hline & Bronchodilator usage & Roemer et al., 1993 & $\begin{array}{l}\text { Asthmatic } \\
\text { children }\end{array}$ & 148,64 & 5.945 \\
\hline & Cough & Pope and Dockery, 1992 & $\begin{array}{c}\text { Asthmatic } \\
\text { children }\end{array}$ & 255,93 & 11.514 \\
\hline & $\begin{array}{c}\text { Lower Respiratory } \\
\text { Symptoms }\end{array}$ & Roemer et al., 1993 & $\begin{array}{l}\text { Asthmatic } \\
\text { children }\end{array}$ & 197,35 & 1.579 \\
\hline & $\begin{array}{c}\text { Congestive Heart } \\
\text { Failure } \\
\end{array}$ & $\begin{array}{c}\text { Schwartz and Morris, } \\
1995 \\
\end{array}$ & Adults over 65 & $\mathbf{0 , 5 5}$ & 1.790 \\
\hline & Chronic cough & Dockery et al., 1989 & Children & 113,39 & 27.219 \\
\hline & $\begin{array}{l}\text { Restricted Activity } \\
\text { Days }\end{array}$ & Ostro, 1987 & Adults & 3253,11 & 357.828 \\
\hline & Chronic Bronchitis & Abbey et al., 1995 & Adults & 3,19 & 539.896 \\
\hline & $\begin{array}{l}\text { Respiratory Hospital } \\
\text { Admissions }\end{array}$ & Dab et al., 1996 & Entire population & 0,47 & 2.041 \\
\hline & $\begin{array}{c}\text { Cerebrovascular } \\
\text { Hospital Admissions }\end{array}$ & Wordley et al., 1997 & Entire population & 1,15 & 19.251 \\
\hline & $\begin{array}{l}\text { Chronic mortality } \\
\text { (YOLL) }\end{array}$ & Pope et al., 1995 & Entire population & 35,85 & 3.459 .149 \\
\hline \multicolumn{5}{|c|}{ Total monetary damage } & 4.492 .453 \\
\hline
\end{tabular}

Table 5 shows the comparison cost-benefit for the different scenarios: it has to be noted that the "proposed level", $1200 \mathrm{mg} \mathrm{NO}_{2} / \mathrm{Nm}^{3}$, dry gas $\mathrm{O}_{2} @ 10 \%$, is usually associated with Low-NOx burner, whereas, according to the reference document on B.A.T., both the flame cooling techniques and the Low-NOx burner can reach very low emission levels (500 mg $\mathrm{NO}_{2} / \mathrm{Nm}^{3}$ ). Moreover, we used the highest costs within the range reported in Table 2 in order to give a clear and univocal interpretation of the comparison. Benefits are calculated with respect to the "no B.A.T." scenario.

As one can easily observe in Figure 1, which shows the cost-benefit analysis in the time (starting from the investment), all the scenarios have strong positive effects if compared with the B.A.T. costs. In particular, for the primary measures, flame cooling and Low $\mathrm{NO}_{\mathrm{X}}$ burners, the break event point (the time at which benefit overcomes cost) is lower than 1 year, even in the case of the "proposed level" scenario. As far as the most expensive scenario is concerned, that is the selective catalytic reduction (SCR), the break event point occurs after 
1 year but the environmental benefits have a large slope factor so that, in the long term, SCR could be the best choice.

Table 5: $\quad$ Cost-benefit analysis.

\begin{tabular}{|c|c|c|c|c|c|}
\hline \multirow{2}{*}{$\begin{array}{l}\text { Emission level } \\
\mathrm{mg} \mathrm{NO}_{2} / \mathrm{Nm}^{3} \\
\text { dry gas, } \mathrm{O}_{2} @ \\
10 \%\end{array}$} & \multirow{2}{*}{$\begin{array}{l}\text { Calculated } \\
\text { environmental } \\
\text { damage }(€ / y)\end{array}$} & \multirow[b]{2}{*}{$\begin{array}{c}\text { Benefit } \\
(€ / y)\end{array}$} & \multicolumn{2}{|c|}{ B.A.T. costs } & \multirow[b]{2}{*}{ notes } \\
\hline & & & $\begin{array}{c}\text { Investment } \\
(€)\end{array}$ & $\begin{array}{c}\text { Operating } \\
(€ / y)\end{array}$ & \\
\hline 1527 & 4.492 .453 & 0 & - & - & no B.A.T. \\
\hline 1200 & 3.525 .114 & 967.339 & 800.000 & - & $\begin{array}{l}\text { Proposed } \\
\text { level }\end{array}$ \\
\hline 500 & 1.469 .066 & 3.023 .387 & 200.000 & 75.000 & $\begin{array}{l}\text { Flame } \\
\text { cooling }\end{array}$ \\
\hline 500 & 1.469 .066 & 3.023 .387 & 800.000 & - & Low-NOx \\
\hline 200 & 585.816 & 3.906 .637 & 4.500 .000 & 60.000 & SCR \\
\hline
\end{tabular}
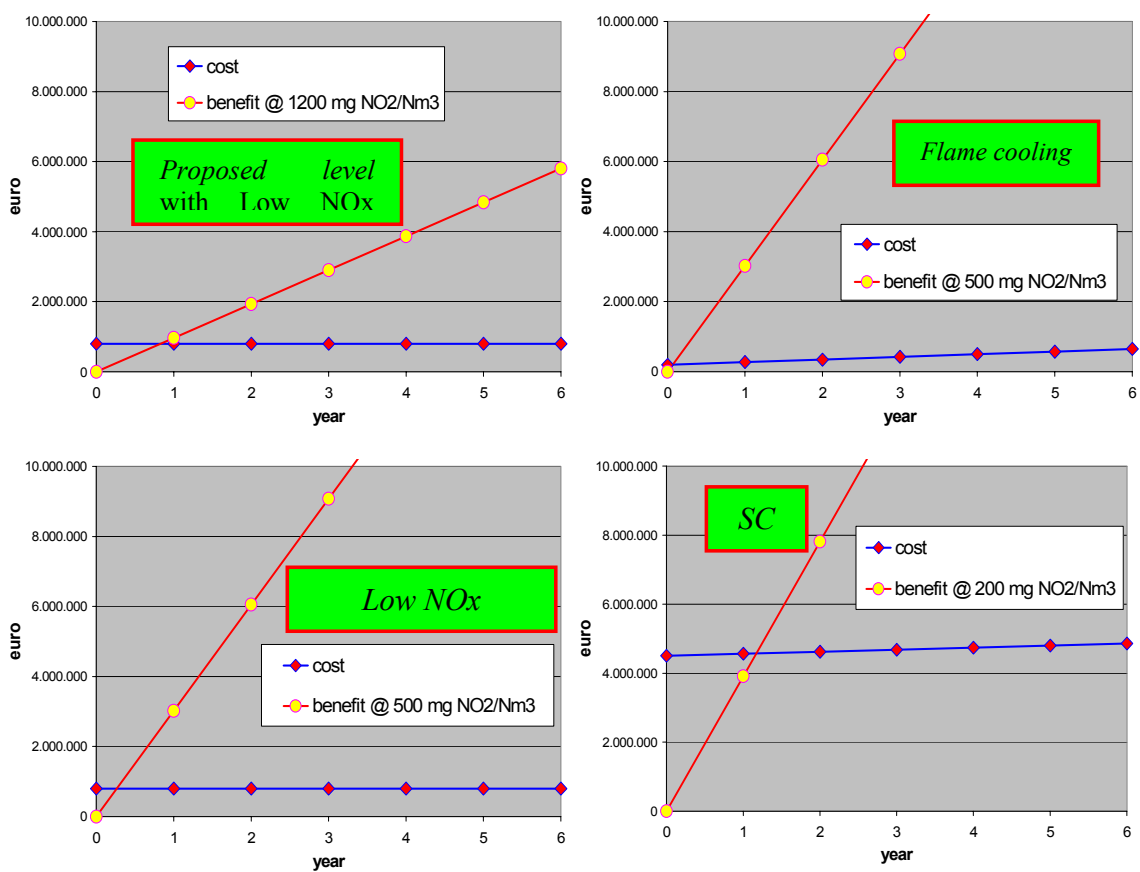

Figure 1: Cost-benefit analysis for the B.A.T. scenarios.

\subsection{The local scale}

So far, we carried out the cost-benefit analysis on the regional scale, which is the approach that gives the most complete information about the impact due to an industrial plant. At the same time we are usually very interested in the damage at 
the local scale, where $\mathrm{NO}_{2}$ has not undergone chemical transformations yet. This way, we determined the $\mathrm{NO}_{2}$ yearly mean concentration at the ground level in a very local scale by means of the Industrial Source Complex Short Term Model, version 3 (ISCST3), by U.S. EPA [5], and then we calculated the impact on human health; to do this, we applied the exposure-response functions for $\mathrm{NO}_{2}$ (Table 6), which are recommended exclusively for sensitivity analyses. In order to carry out the present part of analysis, we investigate 2 different areas: Cuneo, a town of 53.000 inhabitants, placed downwind of the cement factory during the night hours and Roccavione, a village of 2.800 inhabitants, impacted during the day. Figure 2 shows the isoconcentration map of the investigated areas on the basis of the "no B.A.T." emission level $\left(1527 \mathrm{mg} / \mathrm{Nm}^{3}\right.$, expressed as $\mathrm{NO}_{2}$, dry gas, $\mathrm{O}_{2} @ 10 \%$ ) whereas Table 7 reports the corresponding calculated damages. The first comment on these results is that local impact due to $\mathrm{NO}_{2}$ is negligible if compared with the regional damages due to nitrates; this can be explained by the larger number of receptors on a European-wide scale.

Table 6: $\quad$ Exposure-response functions for $\mathrm{NO}_{2}$.

\begin{tabular}{|c|c|c|c|c|}
\hline $\begin{array}{l}\text { Health end } \\
\text { point }\end{array}$ & Reference & receptor & $\begin{array}{c}f_{\text {er }}(\text { cases/year/ } \\
\left.\text { person } / \mu \mathrm{g} / \mathrm{m}^{3}\right)\end{array}$ & $\begin{array}{c}\text { Unit cost } \\
\left(\text { EURO }_{2000} / \text { case }\right)\end{array}$ \\
\hline $\begin{array}{c}\text { Respiratory Hospital } \\
\text { Admissions }\end{array}$ & Ponce de Leon, 1996 & $\begin{array}{c}\text { Entire } \\
\text { population }\end{array}$ & $1,40 \mathrm{E}-06$ & 4.320 \\
\hline $\begin{array}{l}\text { Acute mortality } \\
\text { (YOLL) }\end{array}$ & $\begin{array}{c}\text { Anderson \& Toulomi, } \\
1996\end{array}$ & $\begin{array}{c}\text { Entire } \\
\text { population }\end{array}$ & 2,91E-06 & 165.700 \\
\hline
\end{tabular}

Table 7: $\quad$ Damages on the local scale for the "no B.A.T." scenario.

\begin{tabular}{|c|c|c|c|c|c|}
\hline \multicolumn{6}{|c|}{$\mathrm{NO}_{\mathrm{x}}: 1527 \mathrm{mg} / \mathrm{Nm}^{3}$ dry gas, $\mathrm{O}_{2} @ 10 \%$} \\
\hline & $\begin{array}{c}\text { Health end } \\
\text { point }\end{array}$ & Reference & receptor & \begin{tabular}{|c|} 
Impacts \\
(cases/year)
\end{tabular} & $\begin{array}{c}\text { Damage } \\
\left(\text { EURO }_{2000}\right) / \mathbf{y}\end{array}$ \\
\hline \multirow{2}{*}{$\begin{array}{c}\mathrm{NO}_{2} \\
\text { Cuneo }\end{array}$} & $\begin{array}{l}\text { Respiratory Hospital } \\
\text { Admissions }\end{array}$ & Ponce de Leon, 1996 & $\begin{array}{c}\text { Entire } \\
\text { population }\end{array}$ & 0,0088 & 38 \\
\hline & $\begin{array}{l}\text { Acute mortality } \\
\text { (YOLL) }\end{array}$ & $\begin{array}{l}\text { Anderson \& } \\
\text { Toulomi, } 1996\end{array}$ & $\begin{array}{c}\text { Entire } \\
\text { population }\end{array}$ & 0,0184 & 3.041 \\
\hline \multirow{2}{*}{$\begin{array}{c}\mathrm{NO}_{2} \\
\text { Roccavione }\end{array}$} & $\begin{array}{l}\text { Respiratory Hospital } \\
\text { Admissions }\end{array}$ & Ponce de Leon, 1996 & $\begin{array}{c}\text { Entire } \\
\text { population }\end{array}$ & 0,0067 & 29 \\
\hline & $\begin{array}{c}\text { Acute mortality } \\
\text { (YOLL) }\end{array}$ & $\begin{array}{c}\text { Anderson \& } \\
\text { Toulomi, } 1996 \\
\end{array}$ & $\begin{array}{c}\text { Entire } \\
\text { population }\end{array}$ & $\mathbf{0 , 0 1 3 8}$ & 2.293 \\
\hline \multicolumn{5}{|c|}{ Total monetary damage } & 5.401 \\
\hline
\end{tabular}

Moreover, one can observe that, in spite of the difference of population in the two analysed areas on the local scale, the damages are quite similar; this effect is due to the different $\mathrm{NO}_{2}$ concentrations at the ground level (the yearly mean concentration over Cuneo is $0,12 \mu \mathrm{g} / \mathrm{m}^{3}, 1,70 \mu \mathrm{g} / \mathrm{m}^{3}$ over Roccavione). As a matter of fact, the ExternE methodology consist of a multiplicative approach (Damage $=$ pollutant Concentration $(C) \times$ Population $(P) \times$ Exposure-Response function $\times$ Unit cost); once the exposure-response functions and the corresponding unit cost are assumed, the main parameter to assess the total monetary damage is $\sum \mathrm{C}_{\mathrm{i}} \times \mathrm{P}_{\mathrm{i}}$ (the sum takes into account the different population density and the inhomogeneous concentration level in the calculation area). In 
the present study, the larger mean concentration calculated for Roccavione compensates the smaller population, so that the parameter $\sum \mathrm{C}_{\mathrm{i}} \times \mathrm{P}_{\mathrm{i}}$ is almost the same in the 2 analysed areas.

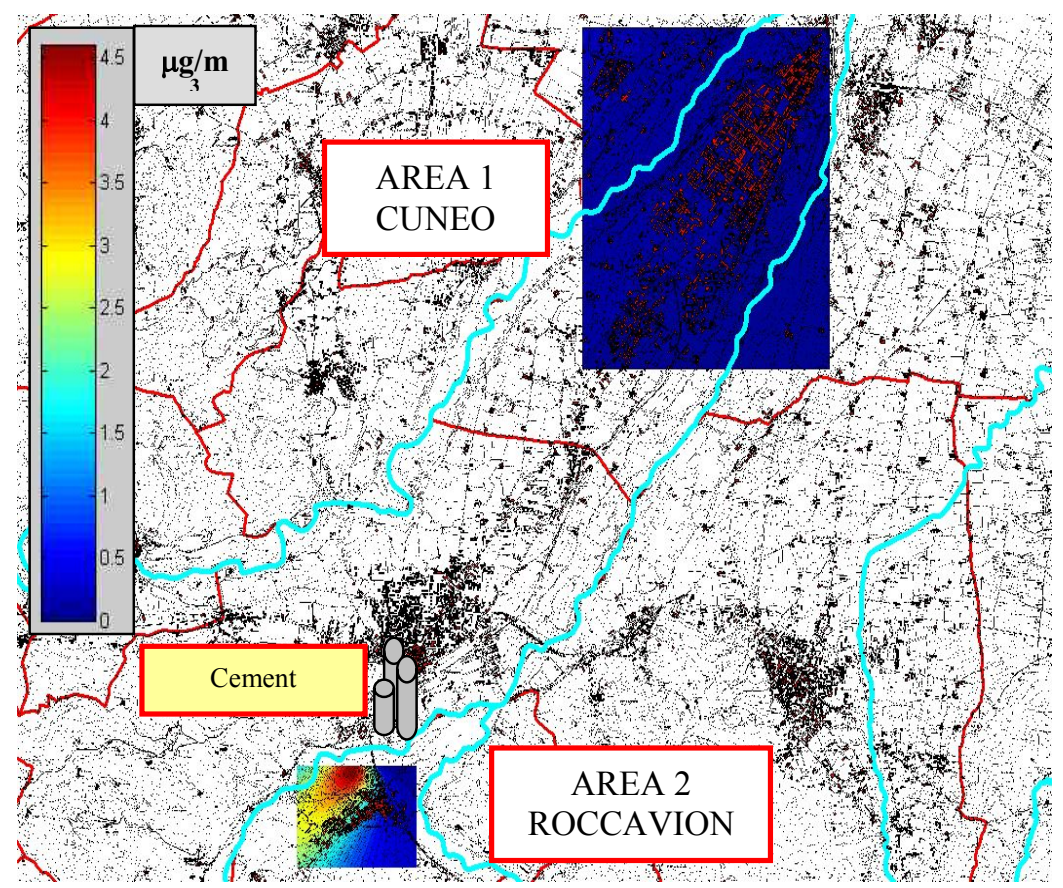

Figure 2: $\quad \mathrm{NO}_{2}$ yearly mean concentrations in the analysed areas.

\section{Conclusions}

The ExternE methodology enables to carry out cost-benefit analysis within the I.P.P.C. authorization procedure; in the present paper we verify that all the B.A.T. proposed to reduce $\mathrm{NO}_{2}$ emissions for long dry rotary cement kiln (flame cooling, Low $\mathrm{NO}_{\mathrm{X}}$ burners, Selective Catalytic Reduction) implicate environmental benefits, due to the reduction of nitrates concentration on a regional scale, which overcome B.A.T. costs after 1 year or less. The benefit deriving from the reduction of $\mathrm{NO}_{\mathrm{X}}$ emissions could be reasonably larger than the calculated one when taking into account the ozone formation or considering that the mixing height assumed by the Windrose Trajectory Model could be lower than $800 \mathrm{~m}$, that is plausible for European areas such as Northern Italy, when temperature inversion phenomena occurs. Another effect that could enlarge the environmental benefit is the stagnation of pollutants at the ground level, due to the very low wind speed of Northern Italy, which is not considered by ordinary dispersion models; this way, the concentration of pollutants, both primary and secondary, can be underestimated. 
As far as the air quality is concerned, the main problem for Northern Italy and large part of Europe comes from particulates ( $\mathrm{PM}_{10}$ or smaller) and ozone; since nitrogen oxides are partly responsible for both the pollutants, any possible effort should be done to reduce their emissions.

\section{References}

[1] European Commission, IPPC, Reference Document on Best Available Techniques in the Cement and Lime Manufacturing Industries, Seville, 2001.

[2] European Commission - DG XII, Externalities of Energy, volume 7: Methodology 1998 update, (EUR 19083 EN), Bruxelles, 1999.

[3] Heck, T., Krewitt, W., Malthan, D., Mayerhofer, P., Pattermann, F., Trukenmuller, A., Ungermann, R., EcoSense 2.0 User's Manual, Universitat Stuttgart, IER, 1997.

[4] Friedrich, R., Bickel, P., Environmental External Costs of Transport, Springer-Verlag, Stuttgart, 2001.

[5] U.S. EPA, User's guide for the Industrial Complex (ISC3) Dispersion Models, Research Triangle Park, North Carolina 27711, 1995. 